\title{
Fotovoltaik-termal (PV/T) bir sistemin deneysel performansinin incelenmesi
}

\author{
Metin GÜL ${ }^{*}, 1$ Ersin AKYÜZ ${ }^{, 2,3}$, \\ ${ }^{1}$ Balıkesir Üniversitesi Fen Bilimleri Enstitüsü, Çă̆ış Kampüsü, Balıkesir. \\ ${ }^{2}$ Balıkesir Üniversitesi Meslek Yüksek Okulu Elektronik ve Otomasyon Bölümü, Çağış Kampüsü, Balıkesir \\ ${ }^{3}$ Balıkesir Üniversitesi Yenilenebilir Enerji Araştırma ve Uygulama Merkezi, Balıkesir
}

Geliş Tarihi (Recived Date): 05.11.2018

Kabul Tarihi (Accepted Date): 01.02.2019

\section{Özet}

Bu çalışmada, Balıkesir Üniversitesi Çağış kampüsünde kurulan hibrit fotovoltaik termal $(P V / T)$ bir sistemin elektriksel ve termal çalışma performanslart incelenmiştir. Kurulan sistemin, şebeke bağımsız olarak akülerle birlikte elektriksel çalışma performansı değerlendirilmiştir. 0.015, 0.044 ve $0.069 \mathrm{~kg} / \mathrm{s}$ ' lik aklşkan hizlarında yapılan ölçümlerde sistemin termal veriminin \%49.9 ile \%52.11 arasında değiştiği görülmüş̧ür. Ăgustos ayı için, belirlenen elektriksel yük profilinde, sistemin şebeke bağımsız elektriksel performans incelemesi sonucunda akülerle yük besleme yaparken şarj durumu \%40 ile \%100 arasında değiştiği belirlenmiştir. Ayrıca PV/T panelin soğutmalı ve soğutması durumlarda elektriksel performansı incelenmiştir ve soğutma

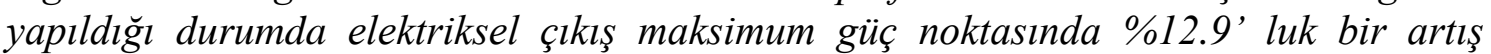
belirlenmiş ve bu değerlerde elektriksel verim \%12 olarak hesaplanmıştır.

Anahtar kelimeler: Hibrit fotovoltaik termal, PV/T, güneş enerjisi, yenilenebilir enerji.

\section{Performance investigation of a hybrid photovoltaic-thermal (PV/T) system}

\begin{abstract}
In this study, electrical and thermal performances of a hybrid photovoltaic thermal system (PV/T) which built in Ballkesir University Campus area were investigated. The off-grid electrical performance of the system with batteries has been evaluated. It is found that the thermal efficiency of this system changes between $49.9 \%$ and $52.11 \%$ by the measurements in 0.015, 0.044 and $0.069 \mathrm{~kg} / \mathrm{s}$ flow rates. In August, the state of
\end{abstract}

\footnotetext{
* Metin GÜL, metingul@balikesir.edu.tr, http://orcid.org/0000-0001-6168-1768

Ersin AKYÜZ, eakyuz@balikesir.edu.tr, http://orcid.org/0000-0001-9786-3221
} 
charge of batteries change between $40 \%$ and $100 \%$ while the system feeds the specified load profile. Additionally, the electrical output of the cooling and uncooling of PV/T panel in the maximum power point were compared resulting approximately $12.9 \%$ increasing power. The electrical efficiency has been calculated as $12 \%$ for cooling system.

Keywords: Photovoltaic thermal, PV/T, solar energy, renewable energy.

\section{Giriş}

Geleneksel enerji kaynaklarına ulaşmadaki zorluklar, yarattığı çevre sorunları ve ülkelerin enerji kullanımında dışa bağımlılığını azaltmak istemesi son yıllarda yenilenebilir enerji yatırımlarının artmasında önemli rol oynamıştır [1]. Fotovoltaik (PV) panel maliyetlerindeki hızlı düşüşle beraber güneş enerjisi, yenilenebilir enerji kaynakları arasında ön plana çıkmıştır. Şekil 1' de 1975 yılından günümüze PV hücre maliyetlerindeki hızlı düşüş ve buna bağlı olarak global kurulu güçteki artış trendi verilmiştir. Gözlenen PV hücre fiyatlarındaki düşüşle birlikte güneş enerjisinden faydalanma konusundaki uygulamalar 2000' li y1llarda hizla artarak 2015 y1linda küresel olarak 64.892 MW güç değerine ulaşmıştır [2]. Ülkemiz güneş enerjisi kurulu gücü açısından 2016 yılında 844 MW ile 25. sıradayken 2017 yılında 3422 MW' lık kapasite ile 13. sıraya yükselmiştir[3]. Güneş enerjisi kurulu gücü 2018 haziran ay1 verilerine göre 4725.9 MW' a ulaşarak çok hızlı bir artış göstermiştir [4].

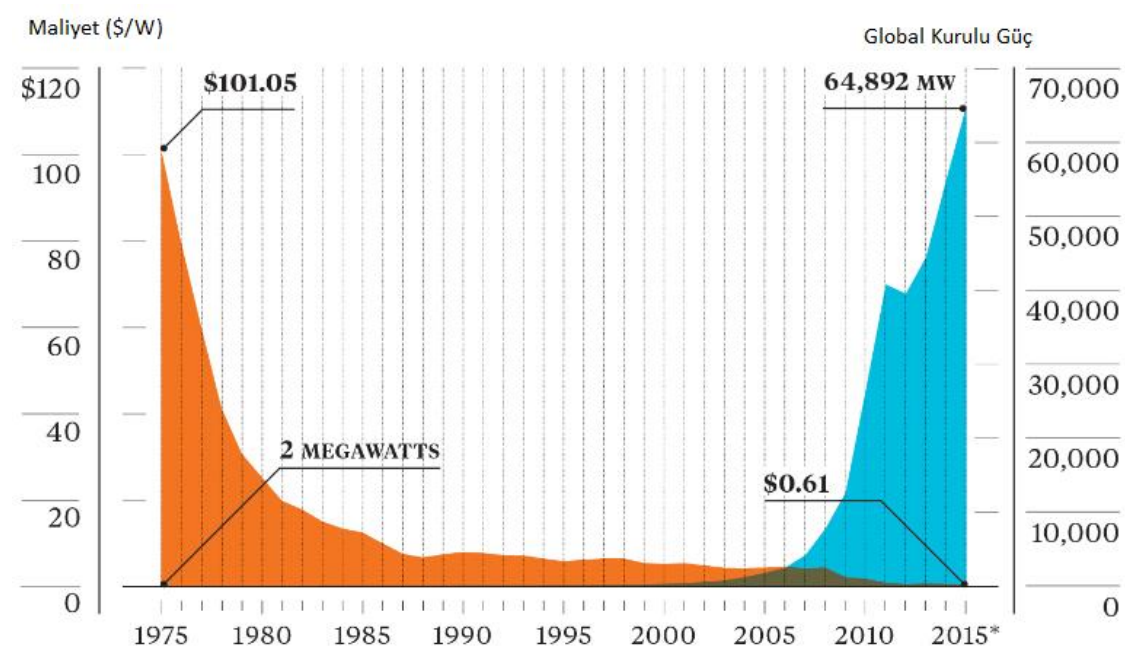

Şekil 1. PV fiyatlarının tarihsel değişimi [2].

Güneş enerjisinden elektrik enerjisi elde etmeye yönelik kullanılan PV hücreler bu işlemi güneşten soğurulan foton enerjisinin dönüşümü ile gerçekleştirmektedir. $\mathrm{Bu}$ enerji dönüşümü için yarı iletken malzemelerle oluşturulmuş yüzeyler kullanılır [6]. PV hücreler tarafindan kullanılan foton enerjisinin büyük kısmı elektrik enerjisine dönüştürülemez ve 1s1 enerjisi olarak sistemde bulunur. Bu 1s1 enerjisi PV hücrelerinin 1sınmasına dolayısıyla elektrik veriminde azalmaya sebep olur. Hücredeki bu sicaklığın bir akışkan yardımı ile çekilmesiyle, sistemin elektrik verimi daha yüksek seviyelere çıkartılabilir. Bun için düzlemsel PV kolektöre bağlı 1sı soğuran elemanlardan oluşan Fotovoltaik/Termal (PV/T) hibrit sistemler kullanılmaktadır. Böylece sistemde eş zamanlı olarak 1sı ve termal enerji üretilmektedir. Bu enerji miktarı, güneş 1şınımına, 
ortam sıcaklığına, rüzgâr hızına, sistemde bulunan elemanların çalışma sicaklığına ve 1sı çekme yöntemine göre değişiklik gösterir [7].

PV/T kollektörlerde, PV hücrede oluşan 1sıyı soğurmak için genellikle hava ya da sıv1 akışkanlar kullanılır. Deneysel çalışmada kullandığımız PV/T kollektör, ısıyı soğurmak için sıvı akışkanın kullanıldığı bir eşanjöre yapıştırılmış polikristal PV modülden (Şekil 2) oluşmaktadır. [8]. PV/T sıvı kolektörün tipik tasarımı, PV modül ve arkasına sabit bir şekilde yerleştirilmiş metal levha ve sıvı emici plakadan oluşmaktadır. PV yüzeyin arkasında sıvı tabii dolaşımla ya da zorlamalı (pompalı) biçimde dolaştırılarak hem PV hücre sıcaklığını düşürür hem de çevreye yayılacak bu ısıyı yararlı, kullanılabilir hale getirir [9]. PV/T sıvı kollektörler içindeki sıvının akışına ve kollektör bileşenlerine göre çeşitli şekillerde sınıflandırılmaktadır. Bu çerçevede en geniş sınıflandırmayı Zondag ve arkadaşları levha ve boru tipi, kanal tipi, serbest akış tip ve iki kanallı çift soğuruculu model olmak üzere yapmışlardır [10].

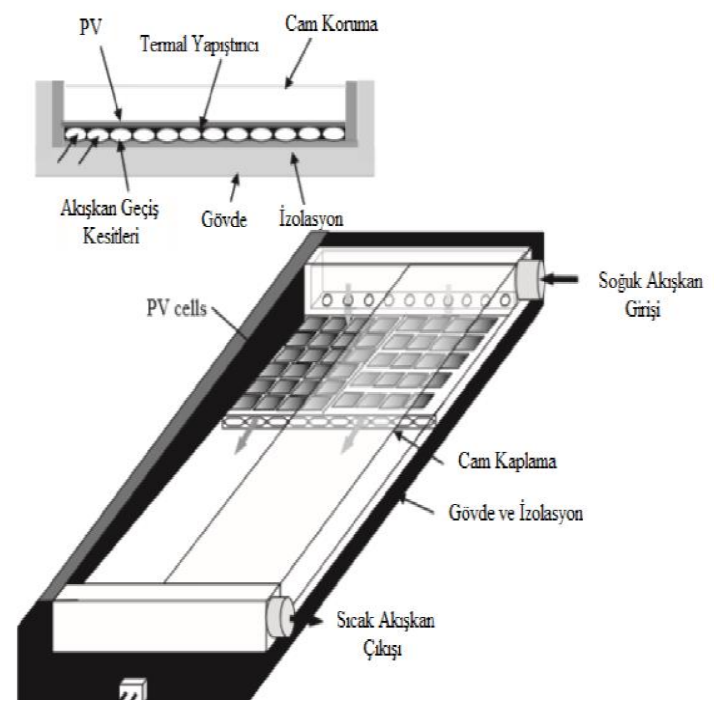

Şekil 2. PV/T sıvı kollektör [8].

PV/T kollektörlerde akışkan olarak havanın kullanıldığı çalışmalar incelendiğinde hava sıcaklığının $20^{\circ} \mathrm{C}$ 'nin üzerinde olduğu durumlarda havanın PV hücre sicaklığını soğutmadaki etkisinin suya göre daha düşük olduğu gözükmektedir [11,12]. P. Rawat ve ark. PV/T hava ve su soğutmalı sistemleri karşılaştırarak toplam sistem verimlerini incelemiş ve sırasıyla \% 62.57 ve \% 70 olarak bulmuşlardır [13]. Bergene ve Lovvik ise PV/T sıvı akışkan sistemlerin enerji analizleri neticesinde toplam verimin \% 60-80 arasında olduğunu hesaplamıştır [14]. Benzer bir çalışmada Fudholi ve ark., PV/T sistemin elektriksel ve termal performanslarını incelemiş, elektriksel verimi $\% 13.8$, termal verimi \% 54.6 olarak bulmuştur. Farklı debilerde yapılan analizlerde akış hızının PV yüzeyindeki soğuma ve termal enerji eldesini etkilediği belirlenmiştir [15].

Ülkemizde farklı coğrafi koşullarda yapılan deneysel çalışmalarda PV/T sistemlerin enerji ve ekserji analizleri gerçekleştirilmiştir. F. Duran Isparta iklim şartlarında PV/T sistemin soğutmalı ve soğutmasız elektriksel performansını incelemiş ve soğutmalı durumda elektriksel verimde $\% 7$ ' lik bir artış gerçekleştiğini hesaplamıştır. Ayrıca incelediği bu sistemin ekserji verimini ortalama \%21 olarak hesaplamıştır [16]. D. Engin çalışmasında, doğal ve zorlanmalı sistemlerin karşılaştırılmasını İzmir iklim 
şartlarında incelenmiştir. Doğal dolaşımlı sistemde verim \%41 olarak hesaplanırken, pompa ile dolaşım sağlandığında verimin \%59' a kadar yükseldiği saptanmıştır [17].

H. İ. Dağ en yüksek verime sahip PV/T sistemi araştırmak için farklı boru çaplarında, dizilimlerde, tabaka tiplerinde ve özdeş PV hücrelere sahip kollektörlerle deneysel çalışmalar yapmıştır. Buna bağlı olarak toplam sistem verimin \% 60.68 ile $\% 67.14$ arasında değişen değerlerini hesaplamıştır [18]. Balıkesir ilinde deneysel ölçümlerle elde edilen meteorolojik veriler 15.08.2017 tarihinden itibaren bir yıllık süre için kayıt edilmiştir. Kurulan sistemin termal ve elektriksel verimlerinin incelenmesinin ötesinde şebeke bağımsız olarak belirlenen bir yük profili için çalışma performansı da değerlendirilmiştir. Bu noktada bu çalışma Balıkesir ilinde bu tip sistem kurulumları için kaynak niteliğinde veri sağlayacaktır.

Bu çalışmada, Balıkesir Üniversitesi kampüsünde kurulan bir PV/T hibrit sistemin deneysel performans değerlendirilmesi yapılmıştır. $\mathrm{Bu}$ amaçla kollektör giriş-çıkış sıcaklıkları, kütlesel akış hızı, hava sıcaklığı, güneş 1şınımı, panel hücre sıcaklığı gibi fiziksel büyüklüklerin ölçümü yapılarak kaydedilmiştir. Aynı zamanda farklı kütlesel akış hızlarında sistemin termal performansı incelenmişti. Sistemin elektriksel performansının belirlenmesi için sistem elektriksel çıkışında maksimum çalışma noktasında ki akım ve gerilim değerleri ölçülmüştür.

Sistemin elektriksel performansının yanında şebeke bağımsız çalışma durumu aküler ve belirlenen bir yük profili ile birlikte değerlendirilmiştir. Bu yüklerin çektiği akım değerleri ile PV/T sistemden çekilen akım değerleri anlık kaydedilip, akü şarj seviyeleri ile sistemin anlık verim değerleri belirlenmiştir.

\section{Deneysel çalışma}

\subsection{Deney düzenĕ̆i}

$\mathrm{PV} / \mathrm{T}$ sistemin elektriksel ve termal özelliklerinin belirlenmesi amacıyla Balıkesir Üniversitesi Çağış Kampüsünde kurulan deney sisteminde iki adet PV/T panel, 100 lt. depo, sirkülasyon pompası, şarj regülatörü, 4 adet $98 \mathrm{Ah}-12 \mathrm{~V}$ jel akü, 1 adet basınç tankı ve 1 adet inverter bulunmaktadır (Şekil 3).

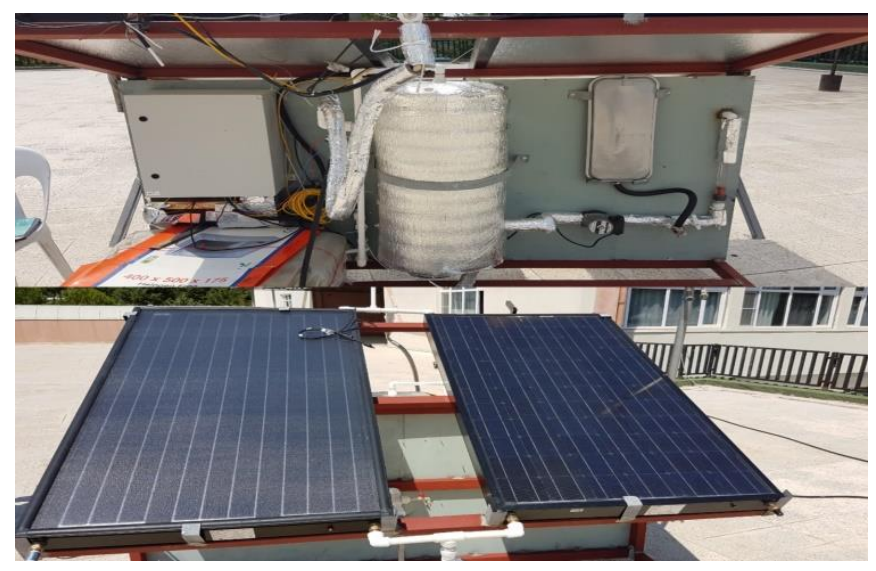

Şekil 3. Balıkesir Çağış kampüsünde kurulan PV/T sistemi. 
Sistemde iki adet $\mathrm{PV} / \mathrm{T}$ ' nin su bağlantıları birbirine bağlanarak bir sirkülasyon pompası yardımıyla depodaki su devridaim edilmiştir. PV/T paneller elektriksel olarak MPPT şarj regülatörü kullanılarak 24 Volt 196 Ah' lik akü barasını beslemektedir. Akü barasına bağlı olan inverter yardımıyla sistemde kullanılacak A.C. elektrik enerji ihtiyacı karşılanmaktadır. İnvertör sistemde bulunan sirkülasyon pompasını, datalogger ve belirlenen yük profiline sahip $3.6 \mathrm{~kW} / g u ̈ n '$ lük A.C. yükleri beslemektedir. Tablo 1 ve Tablo 2' de deney sisteminde kullanılan malzemeler ve özellikleri verilmiştir.

Tablo 1. Deney düzeneğinde kullanılan malzemeler.

\begin{tabular}{ll}
\hline Malzeme Adı & Özelliği \\
\hline Su Deposu & (100 Litre) \\
Şarj Regülatörü & PWM Juta CMP45, 12-24 V, 45 A \\
İnvertör & $1500 \mathrm{~W}$ \\
Akü & Jel Akü Banner 12 V-98 Ah (4 Adet) \\
Sirkülasyon Pompası & Welko 220 V-0.4 A \\
Elektrik yükü & Adet (3) 50 W-220 V \\
\hline
\end{tabular}

Tablo 2. PV/T panel özellikleri.

\begin{tabular}{ll}
\hline Ebatlar & $1640 \times 870 \times 105 \mathrm{~mm}$ \\
Nominal Akım (A) & 5.43 \\
Kısa Devre Akımı (A) & 5.67 \\
Nominal Gerilim (V) & 36.8 \\
Açık Devre Gerilimi (V) & 45.43 \\
Diş Cam & Extra Solar Glass \\
Hücre Sayısı & -2 \\
Soğurucu Yüzey & Monokristal \\
Termal Güç (W) & 680 \\
\hline
\end{tabular}

\section{2 Ölçüm düzenĕği}

Şekil 4' te temel prensip şeması verilen sistemin çalışma performansını incelemek için panel sıcaklıkları, akımları ve akü gerilimleri ölçülmüş ve ölçümler Tablo 3' de verilen ölçüm elemanları kullanılarak gerçekleştirilmiştir. Sistemin soğutmalı ve soğutmasız durumlardaki maksimum çıkış güçlerinin karşılaştırılması için panel çıkış akımgerilimleri ölçülmüştür. Sistemin termal performansının için depo giriş-çıkış sıcaklıkları ve kollektöre giren akışkanın debisi ölçülmüştür. Ayrıca çalışma performanslarının belirlenmesi için gerekli meteorolojik ölçümler (1şınım miktarı, rüzgâr hızı ve hava sıcaklığı) yapılarak datalogger ile kayıt altına alınmıştır.

Campbell Scientific CR1000 veri kaydedicisi yardımıyla, veriler ölçülerek 1, 10 ve 60 dakikalık aralıklar ile kayıt altına alınmıştır.. Dataloggerın giriş ve çıkışlarının programlanabilmesiyle, belirlenen zaman aralıklarında çalışan ve lambalardan oluşan bir yük profili elde edilerek kontrol edilmiştir. Ayrıca sistemdeki pompanın çalışma zamanlaması da datalogger kullanılarak gerçekleştirilmiştir. 


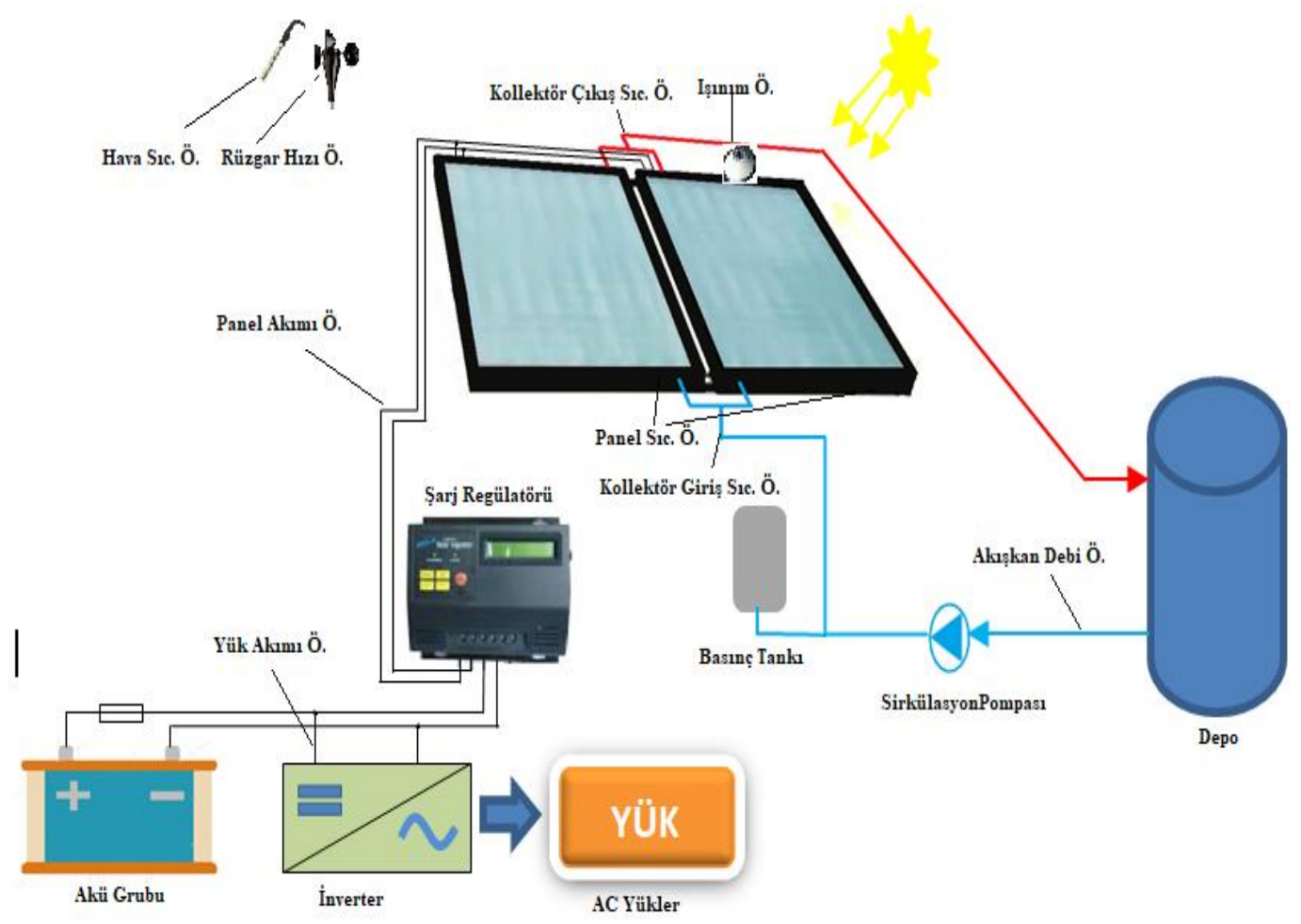

Şekil 4. Hazırlanan PV/T sisteme ait prensip şema.

Tablo 3. Ölçüm sisteminde kullanılan elemanlar.

\begin{tabular}{lll}
\hline Malzeme & Özelliği & Ölçtüğü nicelik \\
\hline Piranometre & Kipp\&Zonen CMP11, & Işınım \\
Anemometre & NRG 40 & Rüzgâr hızı \\
Termokupl & J Tipi & Kollektör giriş çıkış sıcaklık \\
Sicaklık Sensörü & LM35 & Panel sıcaklığı \\
Sicaklık Sensörü & PT100 & Hava sıcaklığı \\
Akım Sensörü & ASC712 & Panel ve yük akımı (0-30A) \\
Debimetre & LZB-15 SL & Akışkan hızı $(25-250 / h)$ \\
\hline
\end{tabular}

\subsection{Sistemin verim ve enerji hesaplamalart}

PV panellerin elektriksel verimleri hesaplamaları Denklem 1 kullanılarak hesaplanmıştır [17].

$\eta_{e}=\frac{V_{M P} \cdot I_{M P}}{I_{T} \cdot A}$

Maksimum güç noktasındaki gerilim değeri $V_{M P}$ olup birimi volttur, IMP maksimum güç noktasındaki akım değeridir ve birimi amperdir. IT birim alana düşen güneş 1şınım miktarıdır, birimi $\mathrm{W} / \mathrm{m}^{2}$, dir ve A panel alanıdır ve birimi $\mathrm{m}^{2}$ dir. 
PV panellerde artan hücre sıcaklığıyla açık devre geriliminde ve doldurma faktöründe önemli ölçüde düşüş ve kısa devre akımında küçük bir artış meydana gelir. Bunun sonucunda elektriksel verimde bir düşüş görülür. Bu etkilere göre elektriksel verim yeniden düzenlenerek Denklem 2' de verilmiştir.

$$
\eta_{e}=\eta_{0}\left(1-\beta_{0}\left(T_{C}-25\right)\right.
$$

Burada $\eta_{0}$ PV hücrenin standart test koşullarındaki $\left(25^{\circ} \mathrm{C}\right.$ hava sicaklığı ve $1000 \mathrm{~W} / \mathrm{m}^{2}$ 1şınım altında) elektriksel verimi ve $\beta_{0}$ sıcaklığa bağımlılık katsayısıdır [19].

Sistemin termal verimi Denklem 3 kullanılarak hesaplanmıştır. Sistemin kütlesel akış hızı, PV/T panele giren akışkanın giriş ve çıkış sıcaklıkları arasındaki fark, akışkanın özgül 1sısı ile doğru orantılı değişen verim toplam yüzeye gelen 1şınımla ters orantılı olarak değişmektedir [20].

$\eta_{t}=\frac{\dot{m} \cdot C_{p} \cdot\left(T_{c}-T_{g}\right)}{I_{T} \cdot A}$

Burada m sistemin kütlesel akış hızı olup birimi kg/s' dir. $\mathrm{C}_{\mathrm{p}}$ kullanılan akışkanın özgül 1sısıdır ve birimi $\mathrm{J} / \mathrm{kg}{ }^{\circ} \mathrm{C}$ ' dir. $\mathrm{T}_{\varrho}$ ve $\mathrm{T}_{g}$ ise sisteme giren akışkanın sıcaklıkları olup birimi ${ }^{\circ} \mathrm{C}^{\prime}$ dir.

\section{Bulgular ve tartışma}

PV/T panelin akışkan yardımıyla soğutmalı ve soğutmasız olarak çalıştırılmasının çalışma performansına etkisinin incelenmesi için, maksimum çalışma noktalarındaki akım-gerilim ve güç değerleri ölçülerek Şekil 5' te karşılaştırmalı olarak verilmiştir. 23.08.2017 tarihinde, $950 \mathrm{~W} / \mathrm{m}^{2}$ 1şınım değeri ve $33{ }^{\circ} \mathrm{C}$ lik hava sicaklığında gerçekleştirilen ölçümlerde soğutmalı panelde 39.9 V olan açık devre gerilimi, soğutmasız panelde 33.2 V olarak ölçülmüşsür. Soğutma yapılmayan panelin çıkış güç değeri $124 \mathrm{~W}$ iken soğutmalı panelin güç çıkışı $140 \mathrm{~W}$ olarak bulunmuştur. Panellerin soğutması durumunda yaklaşık olarak \% 12.9' luk bir güç artışı elde edilmiştir.
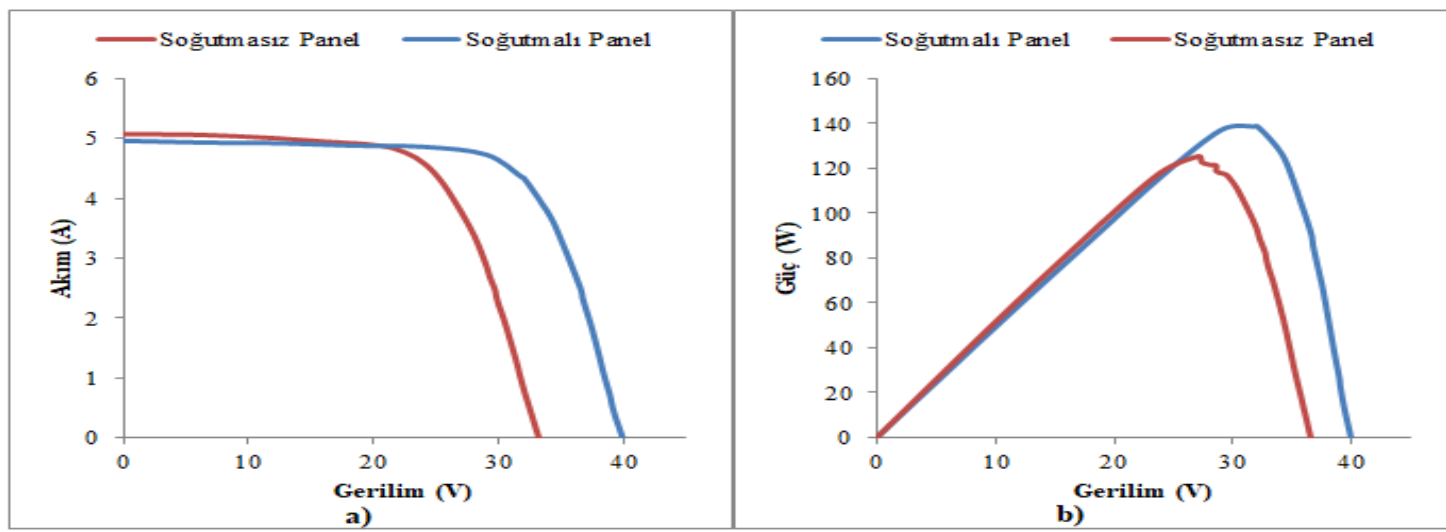

Şekil 5. a) Soğutmalı ve soğutmasız durumda panelin karakteristik akım, gerilim grafiklerinin karşılaştırılması b) Soğutmalı ve soğutmasız durumlardaki panelin maksimum güç noktasındaki değerlerinin karşılaştırılması. 
Soğutma yapıldığı durumda ışınım miktarındaki her $100 \mathrm{~W} / \mathrm{m}^{2}$, lik artışının PV hücre sıcaklığını yaklaşık olarak $2.28{ }^{\circ} \mathrm{C}$ derece arttırdığı görülmüştür. Soğutma yapılmadığ1 durumda ise $4.51^{\circ} \mathrm{C}$ ' lik bir artış olmuştur. Şekil 6' da verilen grafikte bir gün için soğutma yapılan ve soğutma yapılmayan panel için hücre sıcaklık değerleri gösterilmektedir.

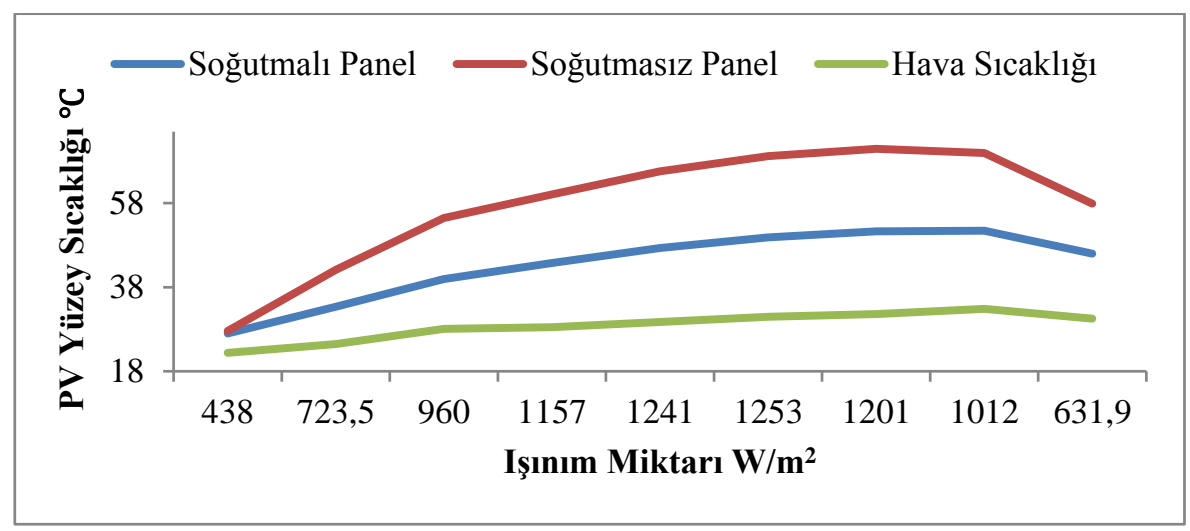

Şekil 6. PV/T hücre sıcaklığı-güneş 1şınımı değişimi grafiği.

PV/T sisteminin Balıkesir şartlarında şebeke bağımsız elektriksel çalışma performanslarının belirlenmesi için yapılan 1şınım ölçümlerinde 15-31 Ağustos 2017 tarihleri arasında 1şınımın en düşük olduğu gün $296 \mathrm{~W} / \mathrm{m}^{2} /$ gün ile 16 Ağustos olurken, en yüksek olduğu gün $443 \mathrm{~W} / \mathrm{m}^{2} /$ gün ile 31 Ağustos' tur.

Şekil 7' de, saatlik 1şınım miktarına göre PV/T paneller tarafından üretilen akım değerleri ile sistem tarafından beslenen yükün çektiği akım ölçüm değerleri verilmiştir. Panellerin belirtilen tarih aralığında sisteme aktardığ toplam akım miktarı $911.091 \mathrm{Ah}$, yükün sistemden çektiği toplam akım miktarı 918.487 Ah olarak hesaplanmıştır. Bu akım değerlerine göre akü barasının şarj durumunun \% 40 ile $\% 100$ arasında değişmiştir.

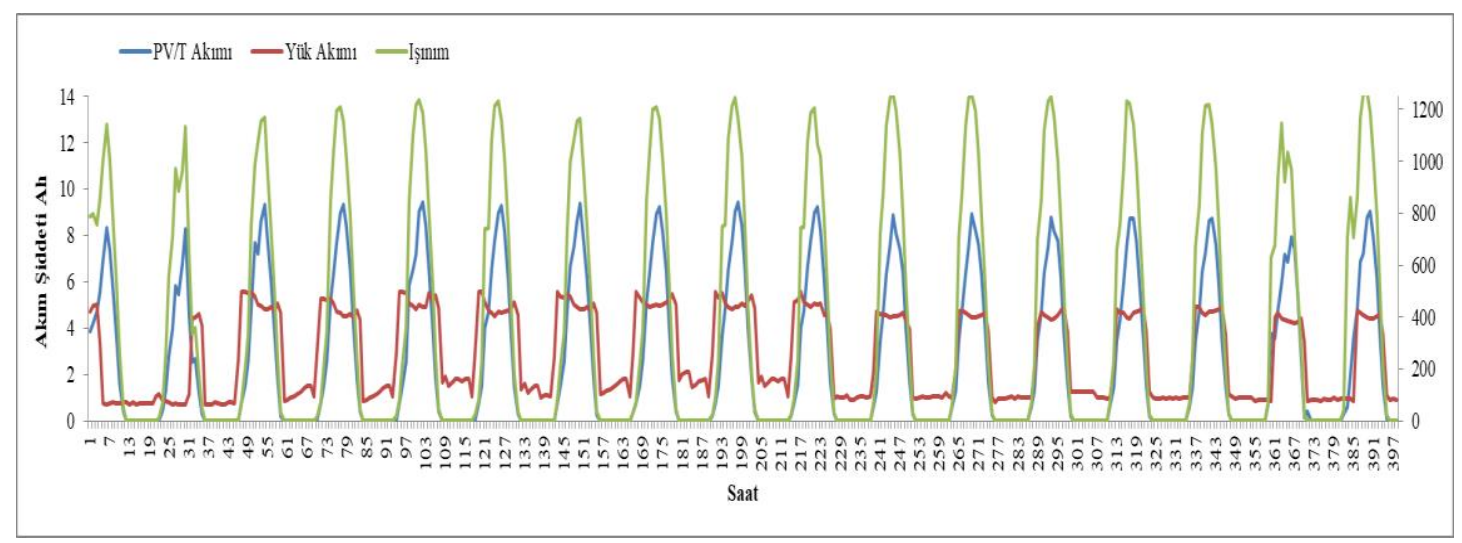

Şekil 7. 15-31 Ağustos tarihleri arasında PV/T panellerin ürettiği ve yükün çektiği akım miktarları ile ışınım miktarı. 
Sonuç olarak 15-31 Ağustos 2017 tarihleri arasında oluşturulan bu sistemde PV/T paneller ile üretilen elektrik enerjisi miktarı $25.788 \mathrm{kWh}$ iken tüketilen elektrik enerjisi miktarı $26.598 \mathrm{kWh}$ olmuştur. Bu tarihler arasında belirlenen yük sistemden üretilenden $0.8 \mathrm{kWh}$ fazla enerji çekmiş olup bu miktar akülerde mevcut enerjiden karşılanmıştır.

Tablo 4' te, 23.08.2017 tarihinde saat 12:30 itibariyle soğutma yapılan panelde maksimum çalışma noktasındaki akım ve gerilim değeri, su giriş ve çıkış sıcaklığı, hava sıcaklığı ve ışınım miktarı verilmiştir.

Tablo 4. PV/T panelin maksimum güç noktasında alınan veriler.

\begin{tabular}{|l|c|c|c|l|c|c|}
\hline Tarih & Gerilim $(\mathrm{V})$ & Akım $(\mathrm{A})$ & $\mathrm{T}_{\mathrm{g}}\left({ }^{\circ} \mathrm{C}\right)$ & $\mathrm{T}_{\mathrm{c}}\left({ }^{\circ} \mathrm{C}\right)$ & $\mathrm{T}_{\mathrm{a}}\left({ }^{\circ} \mathrm{C}\right)$ & $\begin{array}{l}\text { Işııım } \\
\left(\mathrm{W} / \mathrm{m}^{2)}\right.\end{array}$ \\
\hline $23.08 .201712: 30$ & 32.4 & 4.3 & 30.83 & 28.88 & 33 & 950 \\
\hline
\end{tabular}

Tablo 4 ile verilen değerlere göre sistemin elektriksel verimi Denklem 1 kullanılarak $\% 12$ olarak hesaplanmıştır.

$\eta_{e}=\frac{V_{M P} \cdot I_{M P}}{I_{T} \cdot A}=\frac{32,4 V \cdot 4,3 A}{950 W / m^{2} .1,222 m^{2}}=0.12$

Akışkan debisinin sistemin termal performansına etkilerini incelemek için PV/T giriş ve çıkış su sıcaklıkları ölçülerek, akışa bağlı sıcaklık profilleri oluşturulmuştur. Şekil 8' de $0.069 \mathrm{~kg} / \mathrm{s}$ kütlesel debiyle çalışan sistem için su giriş çıkış sıcaklık profili verilmiş olup, ölçülen en düşük sıcaklık farkı $0.51{ }^{\circ} \mathrm{C}$ ve en yüksek sıcaklık farkı $2.15^{\circ} \mathrm{C}$ ' dir. $\mathrm{Bu}$ değerler $0.044 \mathrm{~kg} / \mathrm{s}^{\prime}$ lik debi ile çalışan sistem için $0.93{ }^{\circ} \mathrm{C}$ ile $3.39{ }^{\circ} \mathrm{C}$ ve $0.015 \mathrm{~kg} / \mathrm{s}$ ' lik debi ile çalışan sistem için $2.37^{\circ} \mathrm{C}$ ile $10.12^{\circ} \mathrm{C}$ olarak ölçülmüştür.

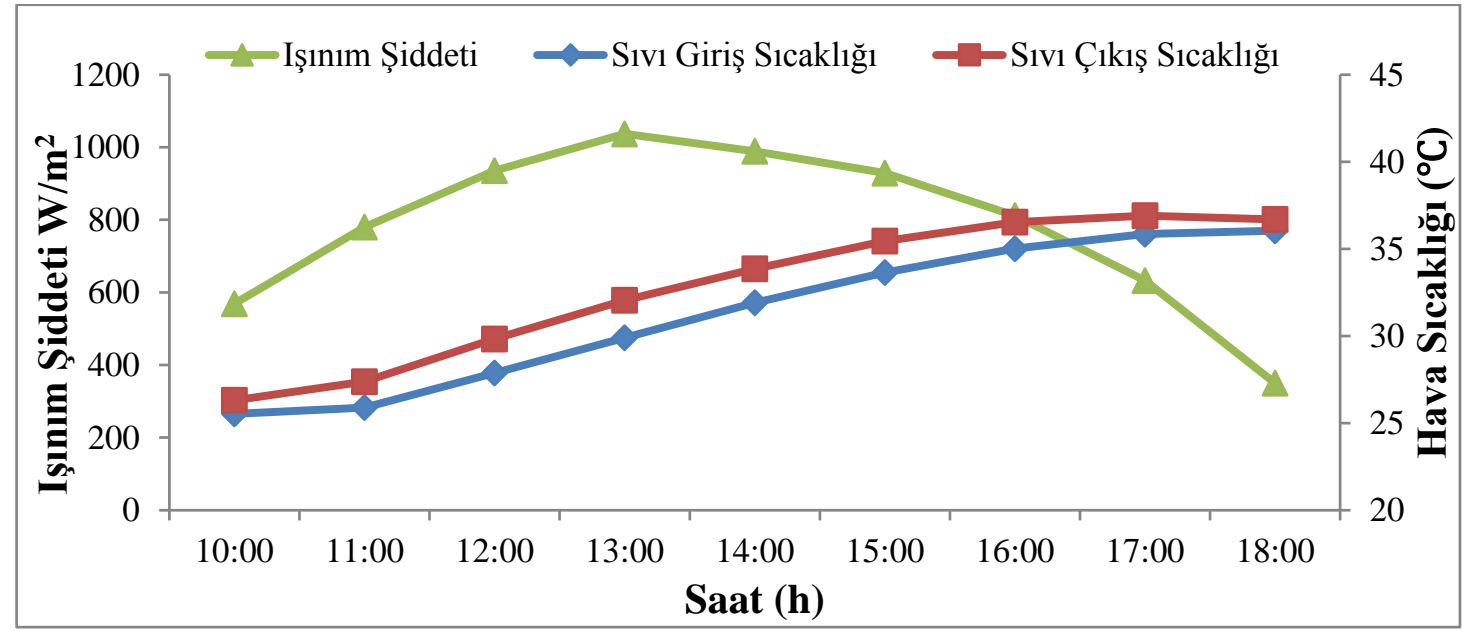

Şekil 8. $0.069 \mathrm{~kg} / \mathrm{s}$ debi değerindeki sıvı giriş-çıkış sıcaklığının ışınıma göre değişim grafiği.

Şekil 9' de 0.069 kg/s' lik debi değerinde 1 şınım miktarına göre su giriş-çıkış sıcaklıkları arasındaki farkı gösteren grafik verilmiştir. Buna göre, bu debi değerinde 1 şınım değerindeki her $100 \mathrm{~W} / \mathrm{m}^{2}$ ' lik artış ile su giriş-çıkış sıcaklığı arasında $0.25^{\circ} \mathrm{C}$ ' lik artış meydana gelmiştir. Bu artış miktarı $0.044 \mathrm{~kg} / \mathrm{s}$ ' lik debi değerinde $0.34{ }^{\circ} \mathrm{C}$ iken $0.015 \mathrm{~kg} / \mathrm{s}$ ' lik debi değerinde ise $0.97{ }^{\circ} \mathrm{C}$ olarak gerçekleşmiştir. 


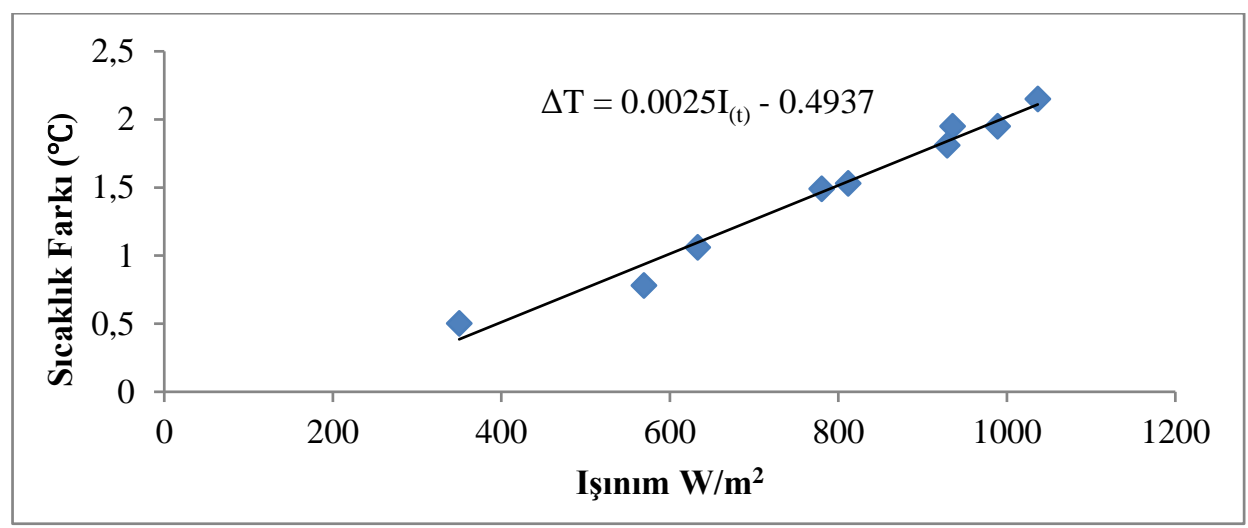

Şekil 9. $0.069 \mathrm{~kg} / \mathrm{s}^{\prime}$ lik debi değerinde su giriş-çıkış sıcaklıkları arasındaki farkın 1şınıma bağlı grafiği.

Farklı debi değerleri için su giriş-çıkış sıcaklıkları farkının ışınıma bağlı denklemleri elde edilerek Tablo 5' te verilmiştir.

Tablo 5. Farklı debilerde sıcaklık farkının ışınım değerine bağlı denklemleri.

\begin{tabular}{|c|c|}
\hline Debi Değeri $(\mathrm{kg} / \mathrm{s})$ & Denklem \\
\hline 0.015 & $\Delta \mathrm{T}=0.0097 \mathrm{I}_{(\mathrm{t})}-0.7058$ \\
\hline 0.044 & $\Delta \mathrm{T}=0.0034 \mathrm{I}_{(\mathrm{t})}-0.3334$ \\
\hline 0.069 & $\Delta \mathrm{T}=0.0025 \mathrm{I}_{(\mathrm{t})}-0.4937$ \\
\hline
\end{tabular}

Şekil 10, 11 ve $12^{\prime}$ de sirasıyla $0.069 \mathrm{~kg} / \mathrm{s}, 0.044 \mathrm{~kg} / \mathrm{s}$ ve $0.015 \mathrm{~kg} / \mathrm{s}$ debi değerleri için yapılan ölçümler ile indirgenmiş sıcaklık farkına göre 1 sıl verim eğrileri elde edilmiştir.

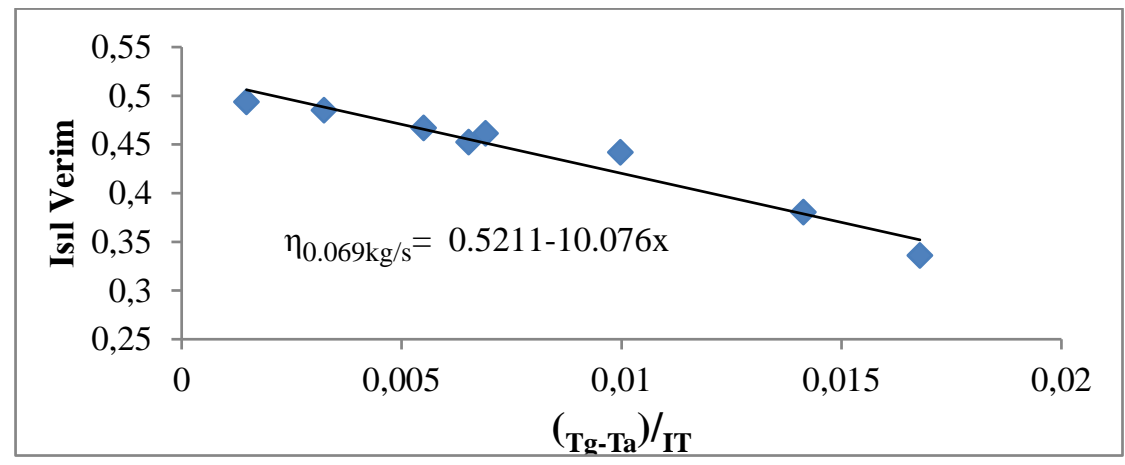

Şekil 10. $0.069 \mathrm{~kg} / \mathrm{s}$ kütlesel debide, 1şınımın giriş ve çıkış su sıcaklık farkları (Tg-To) üzerine etkisi. 


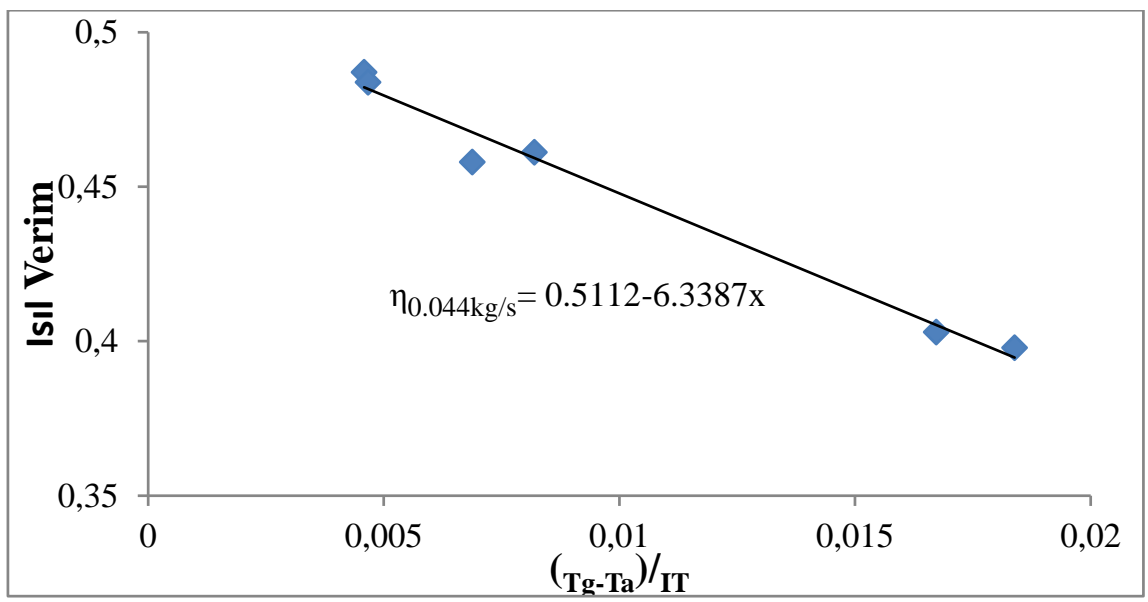

Şekil 11. $0.044 \mathrm{~kg} / \mathrm{s}$ kütlesel debide, 1şınımın giriş ve çıkış su sıcaklık farkları (Tg-To) üzerine etkisi.

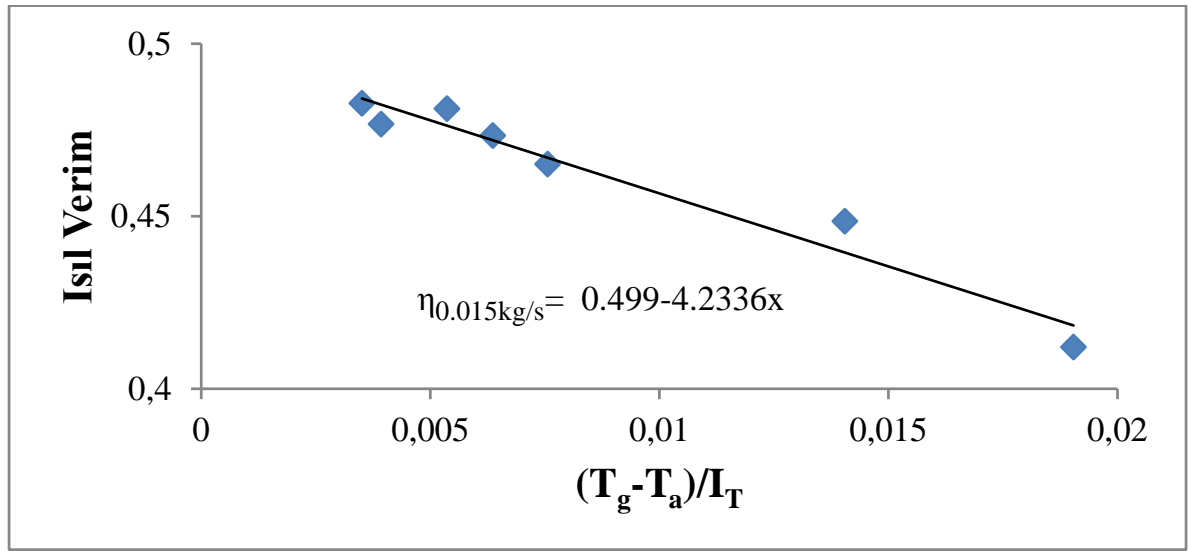

Şekil 12. $0.015 \mathrm{~kg} / \mathrm{s}$ kütlesel debide, 1şınımın giriş ve çıkış su sıcaklık farkları (Tg-To) üzerine etkisi.

Farklı debilerde yapılan ölçümlerde akış hızının artmasının 1sıl verimi arttırdığı belirlenmiştir. Denklemlerdeki sıcaklığa bağlı kayıpları bulmamıza olanak sağlayan ikinci katsayılar incelendiğinde, debi değeri yüksek olan ölçümde bu katsayının yüksek olduğu görülmüştür. Kütlesel debinin artmasının sıcaklığa bağlı kayıpları arttırdığı da gözlemlenmiştir.

Farklı debi değerlerinde yapılan 1sıl verim testlerine göre, elde edilen indirgenmiş sıcaklık farkına göre $\left(\left(\mathrm{T}_{\mathrm{g}}-\mathrm{T}_{\mathrm{a}}\right) / \mathrm{I}_{\mathrm{T}}\right)$ 1sıl verim denklemleri Tablo 6' da verilmiştir

Tablo 6. Farklı debi değerleri için indirgenmiş sıcaklık farkına göre 1sıl verim denklemleri.

\begin{tabular}{|c|l|}
\hline Debi Değeri $(\mathrm{kg} / \mathrm{s})$ & Denklem \\
\hline $0.069 \mathrm{~kg} / \mathrm{s}$ & $\eta_{0.069 \mathrm{~kg} / \mathrm{s}}=0.5211-10.076\left(\mathrm{~T}_{\mathrm{g}}-\mathrm{T}_{\mathrm{a}}\right) / \mathrm{I}_{\mathrm{t}}$ \\
\hline $0.044 \mathrm{~kg} / \mathrm{s}$ & $\eta_{0.044 \mathrm{~kg} / \mathrm{s}}=0.5112-6.3387\left(\mathrm{~T}_{\mathrm{g}}-\mathrm{T}_{\mathrm{a}}\right) / \mathrm{I}_{\mathrm{t}}$ \\
\hline $0.015 \mathrm{~kg} / \mathrm{s}$ & $\eta_{0.015 \mathrm{~kg} / \mathrm{s}}=0.499-4.2336\left(\mathrm{~T}_{\mathrm{g}}-\mathrm{T}_{\mathrm{a}}\right) / \mathrm{I}_{\mathrm{t}}$ \\
\hline
\end{tabular}


Şekil 13' de $0.069 \mathrm{~kg} / \mathrm{s}$ ve $0.015 \mathrm{~kg} / \mathrm{s}$ ' lik debi değerleri için günlük toplam 1 sıl verim değerleri saatlik olarak karşılaştırılmıştır. Sıcaklığa bağlı kayıplar dikkate alındığında gün içerisinde verim değerindeki düşüş miktarları $0.069 \mathrm{~kg} / \mathrm{s}$ debi değerinde daha yüksek olduğu belirlenmiştir. $0.069 \mathrm{~kg} / \mathrm{s}$ ' lik debi değerinde sıcaklığa bağlı olmayan optik verim \% 52.11 seviyelerindedir. Gün içerisinde sıcaklığa bağlı verim düşüşünün en büyük değeri \% 36 olarak bulunmuştur. $0.044 \mathrm{~kg} / \mathrm{s}$ ' lik debi değerindeki optik verim \% 51.12 ve sicaklığa bağlı maksimum verim düşüşü ise \%23 seviyesinde olmuştur. Optik verimi \% 49.9 olan $0.015 \mathrm{~kg} / \mathrm{s}$ ' lik debide alınan ölçümlerde maksimum verim düşüşü \% 19 olarak hesaplanmıştır. Buna göre; sistemin debisinin artmasının sıcaklığa bağlı kayıplarda artışa neden olduğu belirlenmiştir.

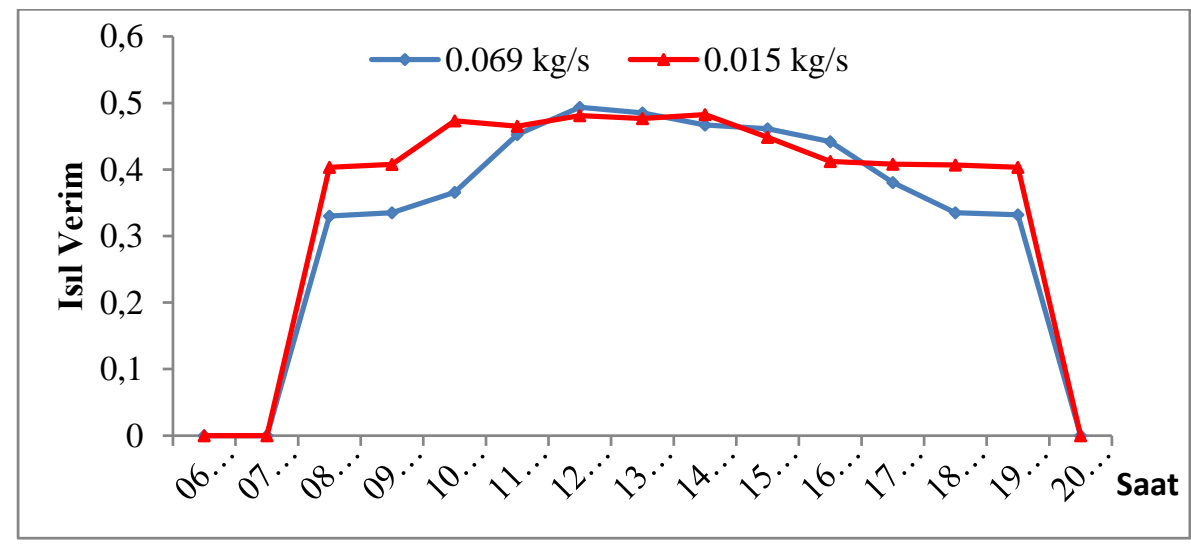

Şekil 13. $0.069 \mathrm{~kg} / \mathrm{s}$ ile $0.015 \mathrm{~kg} / \mathrm{s}$ 'lik debi değerlerinde günlük toplam $1 \mathrm{~s} 11$ verim değerlerinin karşılaştırılması.

PV/T kolektörün $0.069 \mathrm{~kg} / \mathrm{s}$ debi için, maksimum güç noktasında çalıştığ 1 ve elektrik yüksüz çalıştıği durumlarda termal verim değerleri Şekil 14' te karşılaştırılmıştır. Yüksüz durumda termal verim daha yüksek çıkarken sıcaklığa bağlı kayıplar yüklü çalışma durumuna göre yüksektir. Yüksüz çalışma durumunda termal verim \% 59.7 hesaplanırken, yüklü durumdaki verim \% 52.1 olarak hesaplanmıştır. 


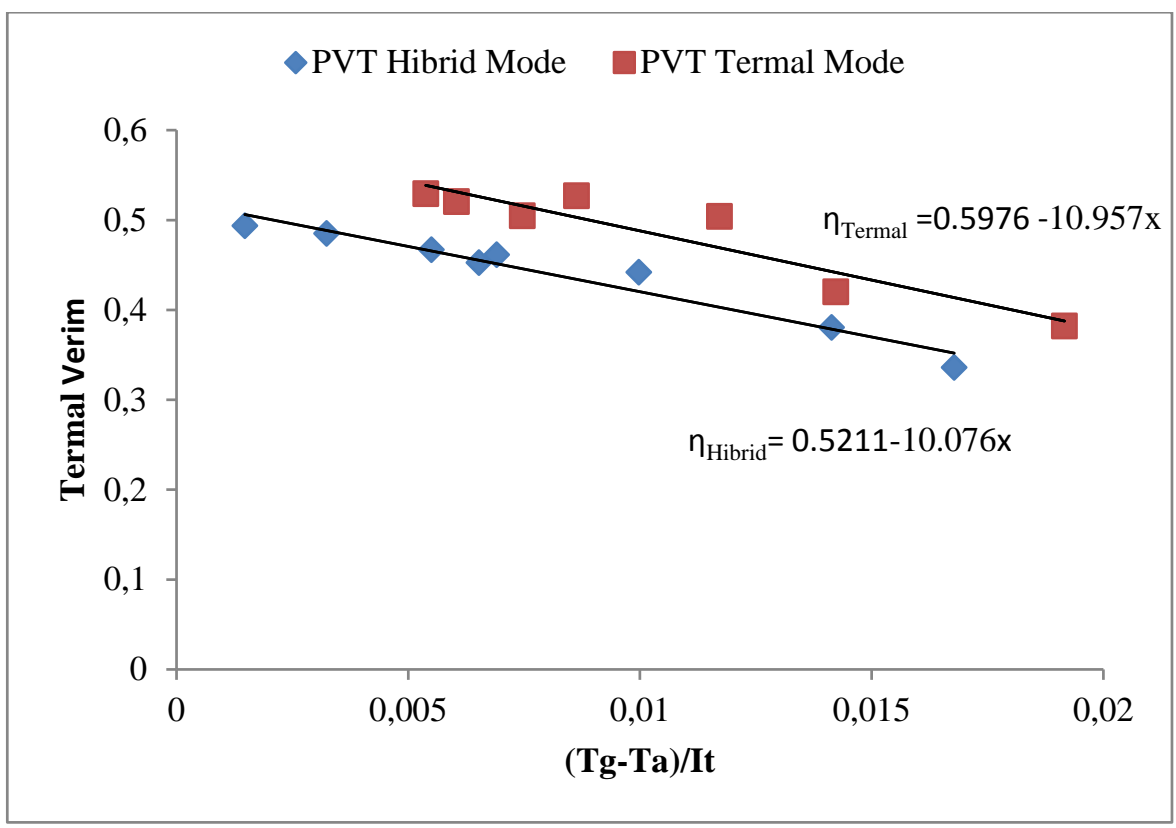

Şekil 14. PV/T Mode-T Mode termal verim karşılaştırılması.

\section{Sonuçlar ve öneriler}

Bu çalışmada Balıkesir Üniversitesi Çağış kampüsünde kurulan PV/T sistemin termal ve elektriksel performansı deneysel olarak incelenmiştir. PV/T panellerin soğutulması için kullanılan sıvı akışkanın panelin maksimum güç noktasındaki elektriksel çıkış gücünde \% 12.9' luk bir artış sağladığ 1 belirlenmiştir.

Farklı debilerde yapılan ölçümlerin termal performansa etkisi incelenmiş ve debiyi arttırmanın termal verimi arttırdığ 52.11 iken $0.015 \mathrm{~kg} / \mathrm{s}$ debide ise \% 49.9 olarak hesaplanmıştır. Farklı debiler için yapılan ölçümlerden elde edilen veriler neticesinde, indirgenmiş sıcaklık farkına göre 1sıl verim denklemleri ve kolektör giriş/çıkış farkının ışınıma bağlı denklemleri elde edilmiştir.

PV/T sistemde, elektriksel yükün termal verime etkisi incelenerek elektriksel yükün devrede olduğu durumda termal verimin \% 52.1 olduğu yüksüz durumda ise termal verim değerinin artarak \% 59.7 olduğu hesaplanmıştır.

Sistemin şebeke bağımsız elektriksel çalışma performansının değerlendirilebilmesi için, 15-31 Ağustos tarihleri arasında elde edilen elektriksel ölçümler neticesinde; sistemden $25.788 \mathrm{kWh}$ elektrik enerjisi elde edilerek akülerde depo edilmiştir. PV/T panellerin ve yük profilinin akülerin şarj durumuna etkisi bu tarihler arasında izlenmiştir ve akü şarj durumunun \% 40-100 aralığında değiştiği gözlemlenmiştir.

Sistemin şebeke bağımsız çalışma performansı ağustos ayı için yeterli olmasına rağmen, $3.6 \mathrm{kWh} /$ gün' lük yük için sistemin kış ayları için yeterli olmayacağı görülmüştür. Panellerin soğutulması için kullanılan deponun daha büyük olmasının panel sıcaklığının düşürülmesi ve elektriksel verimin artmasına olanak sağlayacağı belirlenmiştir. 


\section{Teşekkür}

Bu çalışmaya 2017/056 ve 2017/163 numaralı projeler kapsamında maddi destek sağlayan Balıkesir Üniversitesi Bilimsel Araştırma Projeleri Birimine teşekkür ederiz.

\section{Kaynaklar}

[1] Girgin, M. H., Bir fotovoltaik güneş enerjisi santralinin fizibilitesi, karaman bölgesinde 5 mw’ lik güneş enerjisi santrali için enerji üretim değerlendirmesi ve ekonomik analizi, Yüksek Lisans Tezi, İstanbul Teknik Üniversitesi, Enerji Enstitüsü, (2011).

[2] https://cleahtechnica.com/2016/02/12/is-this-the-best-solar-chart-yet/

[3] https://www.solar.ist/irena-raporuna-gore-gunes-enerjisi-kurulu-gucunde-13siraya-yukseldik/.

[4] https://www.teias.gov.tr/sites/default/files/201807/kurulu_guc_haziran_2018.pdf.

[5] https://www.dunyaenerji.org.tr/wp/content/uploads/2017/10/2009_Youth_Energ y_Report_Wec_Tnc.pdf.

[6] Markvart, T. and Castaner. L., Solar Cells: Materials, Manufacture and Operation, Elsevier Ltd., (2005).

[7] Tripanagnostopoulos, Y., Nousia, T., Souliotis, M. ve Yianoulis, P., Hybrid photovoltaic/thermal solar systems, Solar Energy, 72(3):217-234. (2002).

[8] Cristofari, C., Notton, G., ve Canalett, J. L., Thermal behavior of a copolymer PV/Th solar system in low flow rate conditions, Solar Energy, (83), pages:11231138, (2009).

[9] Du, D., Darkwa, J., Kokogiannakis, G., Thermal management systems for photovoltaics (PV) installations: a critical review, Solar Energy, 97(2):38-54, (2013).

[10] Zondag, H.A., De Vries, D.W., Van Helden, W.G.J., Van Zolingen, R.J.C., Van Steenhoven, A.A., The yield of different combined PV- thermal collector designs, Solar Energy, 74, 253-269, (2003).

[11] Tiwari, G.N., Dubey S., Fundamentals of Photovoltaic Modules and Their Applications, RSC Publishing, Cambridge, (2010).

[12] Kalogirou, S.A., Tripanagnostopoulos, Y., Energy conversion and management 47, 3368-3382, (2006).

[13] Rawat, P., Dhiran, T.S., Comparative Analysis of Solar Photovoltaic Thermal (PV/T) Water and Solar Photovoltaic Thermal (PVT) Air Systems, International Journal of Civil, Mechanical and Energy Science (IJCMES), 3(1), (2017).

[14] Bergene, T., Lovvik, O.M., Model Calculations On A Flat-Plate Solar Heat Collector with Integrated Solar Cells, Solar Energy, 55(6), 453-462, (1995).

[15] Fudholi, A., Sopian, K., Yazd1, M., Ruslan, I., Kazem, H., Performance analysis of photovoltaic thermal (pvt) water collectors, Energy Conversion and Management, 78, s641-651, (2014).

[16] Duran, F., PV/T Hibrit sistemlerin termodinamik ve performans analizi, Yüksek Lisans Tezi, Süleyman Demirel Üniversitesi, Fen Bilimleri Enstitüsü, Isparta, (2014). 
[17] Engin, D., Yapı ile bütünleştirilebilir güneş pili/termal toplayıcı (pv/t) hibrid sistemin performans analizi ve optimizasyonu, Doktora Tezi, Ege Üniversitesi, Fen Bilimleri Enstitüsü, İzmir, (2006).

[18] Dağ, H.İ., Pv-termal kolektörlerin tasarımı, üretimi ve verimini etkileyen parametrelerin belirlenmesi, Doktora Tezi, Ege Üniversitesi, Fen Bilimleri Enstitüsü, İzmir, (2015).

[19] Ceylan, İ., Gürel, A.İ., Demircan, H., Aksu, B., Cooling of a photovoltaic module with temperature controlled solar collector, Energy and Buildings, 72, 96-101, (2014).

[20] Engin D., Çolak M., Yarı-saydam güneş pili/termal toplayıcı (pv/t) hibrid sistemin İzmir koşullarında analizi, Celal Bayar Üniversitesi Soma Meslek Yüksekokulu Teknik Bilimler Dergisi, 2(10), (2008). 